\title{
The Impact of Performance Audit on Public Administrations in Saudi Arabia: An Exploratory Study
}

\author{
Yousef Ali Alwardat ${ }^{1} \&$ Abdullatif Mohamed Basheikh ${ }^{1}$ \\ ${ }^{1}$ Accounting Department, King Abdulaziz University, Saudi Arabia \\ Correspondence: Yousef Ali Alwardat, Accounting Department, King Abdulaziz University, Saudi Arabia. \\ E-mail: yhussain@kau.edu.sa
}

Received: August 18, 2017

doi:10.5539/ijbm.v12n12p144

\author{
Accepted: October 17, 2017 \\ Online Published: November 20, 2017 \\ URL: https://doi.org/10.5539/ijbm.v12n12p144
}

\begin{abstract}
This study aims to examine if auditors of the Saudi Supreme Audit Institution (SSAI) have exerted influence on administrators in Saudi Public Institutions in order to improve the way they manage public resources. The study also examines the impact of the public administrators' personal factors, i.e. the experience and qualifications of administrators on the contributions made by the SSAI, in terms of facilitating the undertaking of changes in the public administrations. The result of a survey of 96 Saudi public officials shows that the SSAI can claim remarkable achievements, in terms of improving Saudi public affairs. Administrators, irrespective of their experience and qualifications, have shown positive perceptions of the process of performance audit and that they are convinced of the usefulness and the quality of the SSAI's reports. This study reveals that the SSAI has contributed towards helping the managements of public organisations define their priorities and adopt both strategic and operational plans. It has also helped them evaluate their projects and services, identify the problems and shortcomings of these projects and services, and then provide valuable recommendations to rectify them.
\end{abstract}

Keywords: performance audit, public sector institutions, a supreme audit institution

\section{Introduction}

The New Public Management (NPM) reform has emerged in some Western Countries since the late 1970s. It was initiated to improve the management of services offered by public sector Administrations (Arnaboldi \& Lapsley, 2008; Grönlund et al., 2011). It has heralded a dramatic change in the role of General Auditors by enhancing the power of Supreme Audit Institutions (SAIs) over public administrations through mandating these institutions to do performance audit (Morin 2014).

Accordingly, performance audit has become a central player in the measurement of public administrations' performance (Benish \& Levi-Faur, 2012; Christensen et al., 2002; Johnsen et al., 2001; Ling, 2007). It covers specific financial operations and all government activities including both organisational and administrative systems (Intosai, 1997). In his Thesis "The Audit Society", Power (1997) argued that performance audit has become an important tools in the reinvention of public sector organisations. He also argued that the SAIs, have strengthen their influence over public administrations and, accordingly, public administrations are producing measures of activity in order to be more accountable and auditable. But he emphasized on the need for more empirical support for these claims.

Several studies in some Western countries have examined the SAIs' performance and their influence on public administrations through performance audit (see for example Morin, 2001, 2008, 2014; De Lancer Julnes, 2006; Van Loocke \& Put, 2011; Reichborn-Kjennerud, 2013a; Reichborn-Kjennerud \& Johnsen, 2015; Raudla, Taro, Agu, \& Douglas, 2015). Other studies have also addressed the impact of auditors' personal factors on the influence of performance audit (Alwardat et al., 2015). But, very little is known about the influence of the Saudi Supreme Audit Institutions (SSAIs) on public administrations, and what factors can enhance or hinder their influence.

For instance, the SSAI was first established in August, 1924 (Safar 1345 Hijri). With its establishment, the Kingdom had a new general audit office with a strong constitutional support and a mandate for conducting traditional financial audit. It was led by the head of the institution which was directly linked with the attorney general and the parliament (Majlis Alshora), and Three members which they were appointed by his Majesty 
King Abdul Aziz. In 1985 (1406 Hijri), the SSAI's mandate has been expanded and the Auditor General became required to report on how well public money are spent (performance audit) as well as conducting traditional financial audit. One consequence of these supplemental powers is that the Auditors General have granted the role to fight against corruption, improper treatment and mismanagement of the public resources.

The 2030 mission that has recently been adopted by the Saudi Government was due to the growing concern for better governance and greater accountability in the management of public funds. Accordingly, all public organisations in the Kingdom have become under scrutiny for their performance. They have also become required to review their performance and be more efficient and effective. The SSAIs are no exception and there role as an instrument to monitor and improve public administrations performance is a matter for concern and should not be taken for granted. Power (1994a) argue that we should not blindly invest in auditing services believing them necessarily to be guarantees of effectiveness (1994b).

There is, to date, no study (to the best of our knowledge) examines the influence of the SSAIs on public administrations, and the contributions that they have made to improve performance in public administrations. Therefore, the purpose of this current study is to fill such a gap in the literature. It aims to assess the SSAIs' performance through examining whether Public Administrations in the Kingdom have complied with the pressure exerted by auditors through applying their recommendations and, accordingly, changed the way they manage public resources. It also examines the impact of the public administrators' personal factors i.e, the experience and qualifications of administrators on the contributions made by the SSAIs to improve performance in public administrations.

This study seeks to enhance the understanding of the influence of performance audits and the contributions they made in improving public administrations performance. There are also two new angles of our study, First: it examines the impact of the administrators personal factors, that have been mentioned above on the process of performance audits and how these factors could facilitate or otherwise, the undertaking of real changes in the way that public money is managed by administrators, and Second; it examines the impact of performance audits in one of the developing countries, which has recently started to adopt the components of performance audits as well as financial audit in its public organisations. Bawole and Ibrahim (2016) suggested that what constitutes good performance in public administrations differs across disciplines, countries and organisations.

The research questions are as follows:

What is the impact of the SSAI on public administrations in the Kingdom of Saudi Arabia?

What is the contribution made by the SSAI, to improve performance in Saudi Public administrations?

What is the impact of the public administrators' personal factors, i.e the experience and qualifications of administrators on the contributions made by the SSAIs, in terms of facilitating the undertaking of changes in the public administrations?

We analysed data from a survey of 96 civil servants, all of whom were administrators, managers (top and middle management) and department professionals who are specialists in their area from different Saudi public administrations. All participants have experienced one or more public sector audit which have been conducted, and interacted with the General Auditors from the SSAIs. The reminder of the article is presented as follows: section 2 presents the literature review. Section 3 addresses the theoretical perspective. Section 4 presents the research methodology. This is followed by the study results and discussion, section 5. Conclusion is presents in section 6 .

\section{Literature Review}

Public sector organisations worldwide have been under constant pressure for the last 15 - 20 years, to improve their performance and win public trust (Pollitt \& Bouckaert, 2004; Talbot, 2010). This has put more pressure on public sector administrations to set up new measurement strategies and enhance comprehensive performance (Pollitt, 2003). As a result, the Supreme Audit Institutions (SAIs) in most countries have become a key part of the institutional framework (Pollitt \& Summa, 1997), and increasingly become active in examining performance of public sector administrations (Talbot and Wiggan, 2010). This performance movements has resulted of more use of audit as a mechanism of improving accountability and control (Hood, 1991; Power, 2003a). The theme emerged is that performance audit has become an important tool to assess whether the economy, efficiency and effectiveness of the use of public money have been met. This is usually conducted by team of expert auditors based on special are criteria of measurement and evaluation (Kells, 2011; Waring \& Morgan, 2007; Intosai, 2004).

In practice, the SAIs considered how particular methods might help identify savings in public 
administrations, help make recommendations to improve performance and accountability, help assess performance and produce relevant information for decision makers in public organisations (Lonsdale, 2000). They also set up performance indicators and a set of targets that should be met by the audited entities in order to prove that public resources are managed properly. Thus the success or otherwise of audited entities in performance audit would be confirmed by the ability to produce evidence on whether performance indicators have been met (Bawole \& Ibrahim, 2016). As a rule, auditors examine these evidences to establish whether public administrations' targets have been met, identify any shortcomings and then write their reports based on the findings. The focus of their reports is usually on the management of service or the implementation of public programs (Keen, 1999). Their reports, in most countries, are presented in the Parliament to enhance accountability in public administrations (Nutley, Levitt, Solesbury, \& Martin, 2012; Pollitt et al., 1999).

They are also expected to contribute to improving administrations' performance by providing public administrations with recommendations to rectify any mismanagement of public resources. To assure compliance with their recommendations, performance auditors usually exert pressure on administrations and make periodic visits to the audited institutions. Even though their recommendations might be perceived by public administrations to be useful, their capability to impact and result in actual changes and improvements in the public administrations should not be taken for granted (Reichborn-Kjennerud \& Johnsen, 2015).

The impact of performance audits on public administrations is an under research topic. In a review of the existing literature, only 14 studies pertaining to the impact of performance audits on public administrations were found (Van Loocke \& Put, 2011). Many of these have examined the perceptions of the audited organisations. Morin (2008) examines the perceptions of public administrators of audit reports and recommendations in order to find out their reactions, especially when auditors left the audited organisations, and to determine factors that enhance or deteriorate auditors' impact. Morin found that auditors' visit have made some effect, although they have not revolutionized auditees' organizational world. She also highlights the importance of the administrators' willingness to cooperate with auditors and adopt better practices. She argues that cooperation between the auditors and auditees can enhance understanding of the issues involved, increase the perceptions of the usefulness of audit, and accordingly, increase the implementation of recommendations (Van Loocke \& Put, 2011; Van Der Meer, 1999). In the same vein, (Alwardat et al., 2015; Reichborn-Kjennerud, 2013) examine auditees' perceptions of performance audits and suggest that the auditees perceptions of the usefulness of performance audit depends on their expectations and perception of the quality of auditors' reports, the relevance of their recommendations and of the SAI as an institution, as well as on their experiences in the process and the degree to which their recommendations have been implemented. This is supported by a study conducted by Reichborn-Kjennerud (2014), which analyses the auditees' perceptions of performance audit. The study found that performance audits were perceived as useful by the majority of the auditees. The study suggests that if auditees agreed to audit criteria and assessments, had favorable opinions of the reports, and believed that the State Audit Institution contributed to accountability and improvement, then they regarded it as useful.

Other studies addressed the impact of personal on performance audits. Morin (2001) and Alwardat et al. 2015 suggest that auditors' style of leadership, their experience, their professional skills, their credibility in the eyes of the auditees and the connotations perceived by the auditees in the influence modes, and the use of statutory power by the auditors, are all factors that could enhance or hinder their impact on public administrations. Morin (2001) has also suggested that the will at staff level and at the top management of the audited organisation, political will and the timing of performance audit, all are environmental factors which might affect the impact of performance audit on auditees.

Justesen and Skaerbek (2010) examined how accountability mechanisms contributed to the auditor's impact and suggested that these are forceful mechanisms in making organisations implemented changes. But According to (Behn, 2001; Bemelmans-Videc et al., 2007), there is a conflict between improving accountability and performance improvement in public administrations, since enhancing accountability through performance audits might discourage innovations and diminish performance in public organisations.

There are also other researchers have focused on learning processes and success factors for performance audit stressing the importance of the compatibility of the opinions of the auditor and the auditee (De Vries et al., 2000; Van der Meer, 1999). Labsley and Pong (2000) and Lonsdale (1999) based the assessment of impact of audit on audit institutions at the local level (Weets, 2011; Johnsen et al., 2001; Tillema \& Ter Bogt, 2010).

In terms of measuring the impact of the SAIs on public administrators, several scholars expressed concern about the real influence exerted by auditors. Power (1997) highlights the difficulties of measuring the impact of performance auditors on administrations. Power asserts that the real influence of auditors can only be measured 
based on the perceptions of auditors or auditees, which comprise high level of subjectivity. The main obstacles, according to Morin (2014) is due to the scarce of objective data on the impact of performance audit and the difficulties in isolating the actions of auditors as a change factor in administrations. This, in Morin's (2014) view, gives rise to magical thinking by the SAIs and Parliaments when it comes to whether performance audit has truly improved performance in public administrations.

\section{Theoretical Perspective}

Agency theory postulates that public sector organisations represent a principle-agent relationship. The public, who are represented by the parliament, are the owners of the economic resources and act as the principals, whereas administrators who are charged with using and controlling these resources act as agents (Jensen and Meckling, 1976). The theory is based on the premise that the agent must periodically account to the principal (the parliament) for the use of public resources. But, public administration theory indicates that the public's lack of control over administrators compels them to rely on auditors to provide an independent evaluation of the use of public resources by administrators.

As discussed in the literature review section, there are two main goals to performance audit: first, to enhance accountability in public administrations, and second, to contribute to the improvement of their performance by providing them with recommendations. These two goals are more likely to be compatible since improving performance in public administrations could be enhanced by the auditors' focus on accountability. As shown in the literature, this accountability and improvement can be attained by auditors collaborating with administrators through applying performance audits and giving recommendations. Depending on the statutory power and hence influence of the auditors', administrators then choose the extent to which they apply these recommendations (Morin, 2001).

Power, as explained by Dahl (1957), is when one social actor can convince another of carrying out a certain action, and influence, according to (Parson, 1963, p. 42), is 'ways of getting results in interaction'. In an organization, power is likely to be strengthened when authority associate with a certain position (Pfeffer, 1981), and in social contexts, this power can consequently strengthen the influence of particular members over others (Pfeffer, 1981; Dahl, 1957). Thus, the power of SSAI' auditors over public administrators can be determined by the former's influencing of the latter to follow recommendations and consequently change the way they manage their accounts.

According to Goldman and Barley (1974), Nichols and Price (1976) and Dunn (1996), clients generally have more power than auditors in a financial audit due to the wide availability of alternative auditors and the scarcity of audit clients. However, that is not the case in the Saudi Public Sector because auditors who apply performance audits are members of the official audit body SSAI, and thus their hiring and replacement is not in the hands of the clients.

Amongst the five sources of power identified by French and Raven (1959) is legitimate power, whereby the target believes that the source has the right to influence the target and that the target should therefore comply. This is the kind of power present between the SSAI' auditors and administrators in the public sector, which explains why administrators rely on the influence exerted by auditors in order to apply recommendations (Pfeffer, 1981). As for performance auditors, their power is based on the fact that they represent formal audit bodies linked to the Government and the fact that the audit tool is recognized as a control function (Morin, 2001)

Another source of power presented by French and Raven (1959) is Reward and Coercive power, whereby the target believes that the source may provide rewards or punishments for the target. Porter et al. (2003) argued that the targets of influence are more likely to comply with the influence agent if they perceive that their cooperation with the influence agent would earn them a reward instead of punishment. Public sector auditors, as Morin (2015) argued, possess no such power. Nonetheless, administrators might have an implicit reward as a result of their cooperation with auditors. Administrators may have an opportunity to express ideas to their authorities, through the audit process, and this opportunity might be considered as a reward, especially when they were unable to convey these ideas, directly, to the authorities (Morin, 2015). In terms of coercive power, the SAIs in most countries are acting as watchdogs for the parliaments, and parliaments may exert indirect influence on administrators to comply with auditors' recommendations.

Expert power, according to French and Raven, is based on the idea that the agent's influence over the target can be increased if the agent is seen to have some specialized knowledge. The SSAI is required by the statutory to conduct performance audit in all public organisations. This opportunity is more likely to enrich their knowledge in public sector affairs. Finally, Referent power refers to the target identifying with the agent or wishing to associate with the agent. 
Since power can be derived from the statutory power and professional experience of either parties, the identification of the sources of power by French and Raven (1959) shows that both the SSAI's auditors and the public administrators may have power over one another. Also, according to Pfeffer (1981), the power of each actor relies on the important of their tasks and their competence to perform these tasks effectively. In the case of the Kingdom, the 2030 mission that are adopted by the Saudi Government, emphasised on the importance of holding administrators accountable for the use of public resources. Accordingly, this presents the importance of the SSAI's tasks and enhance their power over administrators.

Given the fact that the SSAIs are called on to assess the performance of Saudi public administrators and determine how economically, effectively, and efficiently those administrators have managed public resources, it seems reasonable to measure the SSAIs' impact on administrators. This was the broad aim of this study. This is more likely to provide better understanding of the influence of the SSAI through carrying out performance audits and the contributions they made in improving public administrations performance in one of the developing countries, which has recently started to adopt the components of performance audit. The study also examines the impact of the administrators' personal factors, i.e., their experience and qualifications, on the process of performance audits. These factors are more likely to improve administrators' understanding of auditors' missions and accordingly facilitate the undertaking of real changes in the way that public resources are managed by administrators.

To achieve these study aims and objectives, we have adopted Seven elements of measurement . These elements, which have been used by Pollitt et al (1999) and Morin (2004, 2008), are:

- Contribution of performance audits;

- Relevance of auditors' recommendations;

- Preventive effect exerted by performance audits on administrators;

- Influence exerted by performance audits on administrators' management practices;

- Influence exerted by the performance audit on the audited organisations' relations with stakeholders;

- Concrete actions taken by auditors following the performance audit; and

- Personal consequences of audits

\section{The Empirical Study}

To answer this research questions, we have used a survey administered to the Saudi administrators who have experienced one or more performance audit conducted by the SSAIs. The survey was conducted in 2016. We translated the survey questions into Arabic and then translated the data collected into English. The survey was based on a research instrument developed by Morin (2014). The survey consisted of Seven main questions. Each question covers several elements about the impact of the SSAI on public administrations.

The questionnaire was validated with three public administrators who have wide experience in public administration and dealt with the SSAI's auditors. Inquiries - asking for the e-mail addresses of administrators who dealt with the SSAI's auditors were sent to the public bodies that had experienced performance audit. A communication was then sent to each of the respondents explaining the purpose of the study. Respondents were assured that their identity would remain anonymous and the information they provide will be strictly confidential. This added to the validity of the responses obtained. Subsequently, a web-based questionnaire was sent to the respondents.

The survey was sent to 150 administrators and the number of respondents 96 (resulting in response rate of 64\%). The relatively low response rate could be explained by high workload of the participants, and a large number of questions in the survey. The participants are grouped according to their qualifications and the length of their experience. This was considered wise to explain the impact of personal factors on performance audit impact on administrations. Table 1 shows the distribution of participants according to their qualifications and experience. All questions required answers on a 5 - point Likert scale. Participants' answers were transformed into data files for computer analyses. The survey data have been analysed using SPSS software. An ANOVA test was performed to find out whether differences observed between administrators, based on their qualifications and experience, are statistically significant, significance level being established at 0.05 .

\section{Results and Discussion}

\subsection{Contribution of the SSAI}

In the survey, administrators were asked about the contributions made by the SSAI through conducting 
performance audit. In general, Table 1 shows a positive perspective about such audit since it exerts pressure on public authorities to improve performance. SSAI has been perceived as helpful in highlighting some of the wrong administrative and financial behaviors, clearing up a situation and moving it from discussion to action, emphasizing the necessity for change and assist administrators to quickly change those behaviors. The data reveals that auditors usually play both; priori and post-hoc roles. They work with administrators to make a plan for changes and then follow-up the changes that have been adopted by administrators.

Table 1. Mean: (scale item 1 , do not agree at all - scale item 5, totally agree)

\begin{tabular}{|c|c|c|c|c|c|c|c|c|c|c|}
\hline \multirow[b]{2}{*}{ Variable } & \multicolumn{2}{|c|}{ Qualifications } & \multirow[b]{2}{*}{ Postgra-Duates } & \multirow[b]{2}{*}{ Others } & \multirow[b]{2}{*}{ Sig. } & \multicolumn{3}{|c|}{ Experience (in years) } & \multirow[b]{2}{*}{$\begin{array}{l}\text { More } \\
\text { than } 15 \\
\text { yrs }\end{array}$} & \multirow[b]{2}{*}{ Sig. } \\
\hline & $\begin{array}{l}\text { High } \\
\text { school }\end{array}$ & $\mathrm{BA}$ & & & & $\begin{array}{l}\text { Less } \\
\text { than } \\
4 \text { yrs }\end{array}$ & $\begin{array}{l}4-9 \\
\text { yrs }\end{array}$ & $\begin{array}{l}10-14 \\
\text { yrs }\end{array}$ & & \\
\hline $\begin{array}{l}\text { Highlights some of the } \\
\text { wrong administrative and } \\
\text { financial behaviours }\end{array}$ & 3.83 & 3.94 & 3.89 & 4.14 & .931 & 4.31 & 3.86 & 3.96 & 3.84 & .516 \\
\hline $\begin{array}{l}\text { Helps quickly change some } \\
\text { of the wrong administrative } \\
\text { and financial behaviours }\end{array}$ & 3.92 & 3.87 & 3.67 & 4.43 & .437 & 4.23 & 3.82 & 3.83 & 3.86 & .605 \\
\hline $\begin{array}{l}\text { Confirms the need for } \\
\text { change }\end{array}$ & 3.75 & 3.79 & 3.56 & 3.86 & .906 & 4.00 & 3.77 & 3.88 & 3.62 & .584 \\
\hline $\begin{array}{l}\text { Follows-up the changes that } \\
\text { have been accomplished }\end{array}$ & 3.83 & 3.68 & 3.78 & 3.71 & .966 & 3.92 & 3.68 & 3.92 & 3.51 & .429 \\
\hline
\end{tabular}

Notes. Significant at the $* 0.05$, Five-point Likert scale.

In terms of the projects that executed by the public organisations, Table 2 shows that SSAI have a vital role in the success of these projects. Auditors have been perceived as a relevant party to evaluate, promote and support these projects. They also attract the attention of the employees and the management at both strategic and operational levels to some of the discrepancies and problems in these projects. This is more likely improve the quality of the information needed by the decision makers at both levels to overcome and rectify these problems.

Table 2. Qualifications experience

\begin{tabular}{|c|c|c|c|c|c|c|c|c|c|c|}
\hline Variables & $\begin{array}{l}\text { High } \\
\text { school }\end{array}$ & BA & $\begin{array}{l}\text { Postgra- } \\
\text { Duates }\end{array}$ & Others & Sig. & $\begin{array}{l}\text { Less } \\
\text { than } \\
4 \text { yrs }\end{array}$ & $\begin{array}{l}4-9 \\
\text { yrs }\end{array}$ & $\begin{array}{l}10-14 \\
\text { yrs }\end{array}$ & $\begin{array}{l}\text { More } \\
\text { than } \\
15 \text { yrs }\end{array}$ & Sig. \\
\hline $\begin{array}{l}\text { Gets evaluation from } \\
\text { related parties }\end{array}$ & 3.50 & 3.50 & 3.44 & 3.43 & .996 & 3.62 & 3.68 & 3.67 & 3.22 & .171 \\
\hline $\begin{array}{l}\text { Supports/promotes the } \\
\text { evaluation of projects }\end{array}$ & 3.42 & 3.59 & 3.22 & 4.00 & .462 & 4.00 & 3.36 & 3.63 & 3.49 & .316 \\
\hline $\begin{array}{l}\text { Supports management } \\
\text { in the execution of } \\
\text { projects }\end{array}$ & 3.50 & 3.31 & 3.33 & 3.57 & .868 & 3.23 & 3.18 & 3.50 & 3.41 & .694 \\
\hline $\begin{array}{l}\text { Highlights some } \\
\text { discrepancies in } \\
\text { projects and activities } \\
\text { of the authority }\end{array}$ & 3.33 & 3.69 & 3.44 & 3.86 & .597 & 3.85 & 3.36 & 3.67 & 3.70 & .516 \\
\hline $\begin{array}{l}\text { Confirm the need for } \\
\text { the evaluation of } \\
\text { projects which certain } \\
\text { higher management } \\
\text { try not to evaluate }\end{array}$ & 3.67 & 3.68 & 3.11 & 3.3 .43 & .494 & 3.77 & 3.68 & 3.58 & 3.54 & .052 \\
\hline $\begin{array}{l}\text { Help improve the } \\
\text { quality of the } \\
\text { information used in } \\
\text { making decisions }\end{array}$ & 3.58 & 3.62 & 3.00 & 3.86 & .467 & 3.31 & 3.50 & 3.63 & 3.68 & .909 \\
\hline
\end{tabular}

Notes. Significant at the $* 0.05$, Five-point Likert scale. 
In addition, since the main task of the public organisations is to deliver good quality services to the public, administrators where asked whether the SSAI has any impact on improving these services. Table 3 shows that administrators perceive that auditors have the capabilities to monitor the quality of these services, guarantee fair distribution of them and deliver value for money services, since they can help reduce organisations' operational cost.

Table 3. Qualifications experience

\begin{tabular}{|c|c|c|c|c|c|c|c|c|c|c|}
\hline Variables & $\begin{array}{l}\text { High } \\
\text { school }\end{array}$ & BA & $\begin{array}{l}\text { Postgra- } \\
\text { dates }\end{array}$ & others & Sig. & $\begin{array}{l}\text { Less } \\
\text { than } \\
\text { 4yrs }\end{array}$ & $\begin{array}{l}4-9 \\
\text { yrs }\end{array}$ & $\begin{array}{l}\text { 10-14 } \\
\text { yrs }\end{array}$ & $\begin{array}{l}\text { More } \\
\text { than } \\
15 \mathrm{yrs}\end{array}$ & Sig. \\
\hline $\begin{array}{l}\text { Attracts the attention of } \\
\text { officials and employees } \\
\text { to some of the problems } \\
\text { /shortages of certain } \\
\text { services }\end{array}$ & 3.92 & 3.93 & 3.67 & 3.43 & .494 & 4.08 & 4.14 & 3.46 & 3.89 & .052 \\
\hline $\begin{array}{l}\text { Attracts the attention of } \\
\text { higher management to } \\
\text { some of the problems or } \\
\text { shortcomings in the } \\
\text { performance of the } \\
\text { authority }\end{array}$ & 3.75 & 3.94 & 3.67 & 3.86 & .467 & 4.15 & 3.77 & 3.83 & 3.89 & .682 \\
\hline $\begin{array}{l}\text { Help reduce operational } \\
\text { costs }\end{array}$ & 3.42 & 3.50 & 3.11 & 3.29 & .741 & 3.54 & 2.95 & 3.63 & 3.57 & .102 \\
\hline
\end{tabular}

As discussed in the theoretical perspective section that one of the central goals to the SSAIs is to enhance accountability in public administrations. Table 4 shows that the SSAI helps find a more trustworthy control system, increase the effectiveness of the authority by simplifying the control systems and getting rid of complex once, and sets controls to ensure the integrity of the decisions taken by the authority.

Table 4. Qualifications experience

\begin{tabular}{|c|c|c|c|c|c|c|c|c|c|c|}
\hline Variables & $\begin{array}{l}\text { High } \\
\text { school }\end{array}$ & BA & $\begin{array}{l}\text { Postgra- } \\
\text { Duates }\end{array}$ & others & Sig. & $\begin{array}{l}\text { Less } \\
\text { than } 4 \\
\text { yrs }\end{array}$ & $\begin{array}{l}4-9 \\
\text { yrs }\end{array}$ & $\begin{array}{l}10-14 \\
\text { yrs }\end{array}$ & $\begin{array}{l}\text { More } \\
\text { than } \\
15 \text { yrs }\end{array}$ & Sig. \\
\hline $\begin{array}{l}\text { Helps find a more } \\
\text { trustworthy control system }\end{array}$ & 3.67 & 3.91 & 3.33 & 3.86 & .305 & 4.23 & 3.77 & 3.92 & 3.65 & .230 \\
\hline $\begin{array}{l}\text { Sets controls to ensure the } \\
\text { integrity of the decisions } \\
\text { taken by the authority }\end{array}$ & 4.00 & 3.79 & 3.22 & 3.57 & .212 & 3.92 & 3.59 & 3.75 & 3.78 & .750 \\
\hline $\begin{array}{l}\text { Helps increase the } \\
\text { effectiveness of the authority } \\
\text { by simplifying the control } \\
\text { systems and getting rid of } \\
\text { complex control systems }\end{array}$ & 3.83 & 3.59 & 3.11 & 3.71 & .418 & 3.77 & 3.45 & 3.42 & 3.70 & .579 \\
\hline
\end{tabular}

\subsection{Relevance of Auditors Recommendations}

Administrators were asked about the appropriateness of the recommendations which given by the SSAI' auditors in order to improve performance of public organisations.

Table 5 shows that, on average, auditors' recommendations have been perceived as having a positive impact on public organisations' performance. Although, some recommendations were seen as too vague and difficulty to be applied, but the majority were seen as theoretically valid, applicable, realistic and appropriate to the specific 
organisation's problems. All administrators irrespective of their qualifications and the length of their experiences, all had this perceptions about auditors' recommendations (ANOVA test shows that differences observed between administrators are not statistically significant).

Table 5. Qualifications experience

\begin{tabular}{|c|c|c|c|c|c|c|c|c|c|c|}
\hline Variable & $\begin{array}{l}\text { High } \\
\text { school }\end{array}$ & BA & $\begin{array}{l}\text { Postgra- } \\
\text { Duates }\end{array}$ & others & Sig. & $\begin{array}{l}\text { Less } \\
\text { than } 4 \\
\text { yrs }\end{array}$ & $\begin{array}{l}4-9 \\
\text { yrs }\end{array}$ & $\begin{array}{l}10-14 \\
\text { yrs }\end{array}$ & $\begin{array}{l}\text { More } \\
\text { than } \\
15 \mathrm{yrs}\end{array}$ & Sig. \\
\hline $\begin{array}{l}\text { Recommendations are } \\
\text { theoretically valid, } \\
\text { appropriate to organisations' } \\
\text { problems, realistic and } \\
\text { applicable. }\end{array}$ & 2.61 & 2.61 & 2.57 & 2.47 & .157 & 2.97 & 2.52 & 2.47 & 2.58 & .195 \\
\hline
\end{tabular}

Notes. Significant at the $* 0.05$, Five-point Likert scale.

\subsection{Preventive Effect Exerted by the SSAI on Administrators}

As discussed in the theoretical perspective section that the SSAI enjoys a statutory power since they are acting as watchdogs for the government. This has enhanced its preventive effect felt by administrators in public organisations. Table 6 shows that this preventive effects appears in different forms: First, they (administrators) tend to comply with the laws and regulations governing their organisations; Second, they make considerable efforts to set up effective control systems in order to reduce fraud, dishonesty and waste of public resources; Third, they implement more efficient management practices which results of identifying more accurate and reliable performance indicators, and producing more reliable information about their organisations' performance. Means indicate that whatever administrators' qualifications or the length of their experience, the preventive effect thus exerted by the SSAI is highly influential (differences observed in the means are not statistically significant).

Table 6. Qualifications experience

\begin{tabular}{|c|c|c|c|c|c|c|c|c|c|c|}
\hline Variable & $\begin{array}{l}\text { High } \\
\text { school }\end{array}$ & $\mathbf{B A}$ & $\begin{array}{l}\text { Postgra- } \\
\text { duates }\end{array}$ & Others & Sig. & $\begin{array}{l}\text { Less } \\
\text { than } 4 \\
\text { yrs }\end{array}$ & $\begin{array}{l}4-9 \\
\text { yrs }\end{array}$ & $\begin{array}{l}10-14 \\
\text { yrs }\end{array}$ & $\begin{array}{l}\text { More } \\
\text { than } \\
15 \mathrm{yrs}\end{array}$ & Sig. \\
\hline $\begin{array}{l}\text { Compliance with the laws } \\
\text { and regulations, reducing } \\
\text { fraud, implementing } \\
\text { effective control systems, } \\
\text { defining reliable } \\
\text { performance indicators and } \\
\text { producing more reliable } \\
\text { information about the } \\
\text { organisation's performance. }\end{array}$ & 4.12 & 3.81 & 3.98 & 4.02 & .512 & 4.00 & 3.75 & 4.01 & 3.83 & .613 \\
\hline
\end{tabular}

Notes. Significant at the $* 0.05$, Five-point Likert scale.

\subsection{Influence Exerted by the SSAI on Organisations' Management Practices}

The survey data indicated that the SSAI has a remarkable influence on management practices, whatever participants' qualifications and experience (differences observed in means are not statistically significant). Table 7 shows that the SSAI has influenced the management of public organisations to review their practices in order to deliver value for money services and guarantee a fair distribution of these services. It has encourage them to adopt strategic plans which could be executed over several years, as well as annual operational plans. It has also emphasized on the continues development process of the society. Management of public organisations become required to be open mind, listen to the public in order to have a feedback and then communicate this feedback to the decision makers to make rational decisions. It is also required to intensify efforts in personnel training to 
make people capable of undertaking and executing public sector projects.

Table 7. Qualifications experience

\begin{tabular}{|c|c|c|c|c|c|c|c|c|c|c|}
\hline Variable & $\begin{array}{l}\text { High } \\
\text { school }\end{array}$ & BA & $\begin{array}{l}\text { Postgra- } \\
\text { duates }\end{array}$ & Others & Sig. & $\begin{array}{l}\text { Less } \\
\text { than } 4 \\
\text { yrs }\end{array}$ & $\begin{array}{l}4-9 \\
\text { yrs }\end{array}$ & $\begin{array}{l}10-14 \\
\text { yrs }\end{array}$ & $\begin{array}{l}\text { More } \\
\text { than } \\
15 \mathrm{yrs}\end{array}$ & Sig. \\
\hline $\begin{array}{l}\text { SSAI has influenced } \\
\text { management practices related } \\
\text { to work organisation, defining } \\
\text { of priorities, adopting strategic } \\
\text { plans and to management } \\
\text { information used in } \\
\text { decision-making. }\end{array}$ & 3.80 & 3.50 & 3.38 & 3.38 & .724 & 3.95 & 3.51 & 3.65 & 3.29 & .165 \\
\hline
\end{tabular}

Notes. Significant at the $* 0.05$, Five-point Likert scale.

\subsection{Influence Exerted by the SSAI on Public Organisations'Relations with Stakeholders}

Administrators were asked whether the SSAI has improved or otherwise, the relations between public organisations and different interest groups in the Saudi society. Table 8 shows high values of all means, irrespective of participants' qualifications and experience(differences observed in means are not statistically significant). This indicates to a positive influence of the SSAI on all potential interest groups.

By and large, data analysed so far reveals a positive impact of the SSAI on public organisations. This implicitly means that the credibility of these organisations, in the eyes of the public, has improved since they are fulfilling their duties towards the Saudi society and satisfy all interest groups gravitating around them. These interest groups to an audited organisation might include citizens who are the clients of that particular organization, potential partners (other public organisations) and the legislative party like parliamentarians.

Table 8. Qualifications experience

\begin{tabular}{|c|c|c|c|c|c|c|c|c|c|c|}
\hline Variable & $\begin{array}{l}\text { High } \\
\text { school }\end{array}$ & BA & $\begin{array}{l}\text { Postgra- } \\
\text { Duates }\end{array}$ & Others & Sig. & $\begin{array}{l}\text { Less } \\
\text { than } 4 \\
\text { yrs } \\
\end{array}$ & $\begin{array}{l}4-9 \\
\text { yrs }\end{array}$ & $\begin{array}{l}10-14 \\
\text { yrs }\end{array}$ & $\begin{array}{l}\text { More } \\
\text { than } \\
15 \text { yrs }\end{array}$ & Sig. \\
\hline $\begin{array}{l}\text { SSAI has improved relations } \\
\text { between the citizens and public } \\
\text { organisations, between } \\
\text { legislatives (parliamentarians) } \\
\text { and executive agencies like } \\
\text { ministries and improve the public } \\
\text { organisations credibility in the } \\
\text { eyes of the public. }\end{array}$ & 3.63 & 3.40 & 3.29 & 3.37 & .684 & 3.97 & 3.28 & 3.29 & 3.45 & .148 \\
\hline
\end{tabular}

Notes. Significant at the $* 0.05$, Five-point Likert scale.

5.6 Concrete actions taken by auditors following the performance audit

The survey data indicates to a revolutionary impact of the SSAI on public organisations. Thought the SSAI helps fueling both organizational and legislative changes. Data analysed reveals that the SSAI has influenced audited organisations to the extent that they undertook a major reform of their current programs, projects and their information systems. Targeted organisations have adopted new recruitment policies in order to improve their efficiency and effectiveness. They also reformed their governance policy by amending their current laws and regulations and adopted new once. Once again, it is obvious from Table 9 that this perceptions of the SSAI' revolutionary influence on public organisations is the same regardless of the participants' qualifications and experience (differences observed in the means are not statistically significant). 
Table 9. Qualifications experience

\begin{tabular}{|c|c|c|c|c|c|c|c|c|c|c|c|}
\hline Variable & $\begin{array}{l}\text { High } \\
\text { school }\end{array}$ & BA & $\begin{array}{l}\text { Postgra- } \\
\text { duates }\end{array}$ & Others & Sig. & $\begin{array}{l}\text { Less } \\
\text { than } \\
\text { yrs }\end{array}$ & 4 & $\begin{array}{l}4-9 \\
\text { yrs }\end{array}$ & $\begin{array}{l}10-14 \\
\text { yrs }\end{array}$ & $\begin{array}{l}\text { More } \\
\text { than } \\
15 \mathrm{yrs}\end{array}$ & Sig. \\
\hline $\begin{array}{l}\text { The SSAI' causes reorganising } \\
\text { public organisations, reforming } \\
\text { organisations' programs and } \\
\text { operations, changing their } \\
\text { information system, reforming } \\
\text { current laws or regulations and } \\
\text { recruiting additional staff or get } \\
\text { rid of existing once. }\end{array}$ & 3.56 & 3.39 & 3.44 & 3.19 & .806 & 3.45 & & 3.40 & 3.44 & 3.36 & .980 \\
\hline
\end{tabular}

Notes. Significant at the $* 0.05$, Five-point Likert scale.

\subsection{Personal Consequences of Audits}

It is obvious from Table 10 that all participants, whatever their qualifications and experience, are satisfied with the performance of the SSAI in terms of its influence on public employees. Administrators argued that the SSAI has encouraged employees to be more efficient and more effective. They become forward looking and more confident to take new tasks, initiatives and inclined to focus on strategic plans through adopting long-term objectives instead of short-term once.

Table 10. Qualifications experience

\begin{tabular}{|c|c|c|c|c|c|c|c|c|c|c|}
\hline Variable & $\begin{array}{l}\text { High } \\
\text { school }\end{array}$ & BA & $\begin{array}{l}\text { Postgra- } \\
\text { Duates }\end{array}$ & Others & Sig & $\begin{array}{l}\text { Less } \\
\text { than } 4 \\
\text { yrs } \\
\end{array}$ & $\begin{array}{l}4-9 \\
\text { yrs }\end{array}$ & $\begin{array}{l}10-14 \\
\text { yrs }\end{array}$ & $\begin{array}{l}\text { More } \\
\text { than } \\
15 \text { yrs } \\
\end{array}$ & Sig. \\
\hline 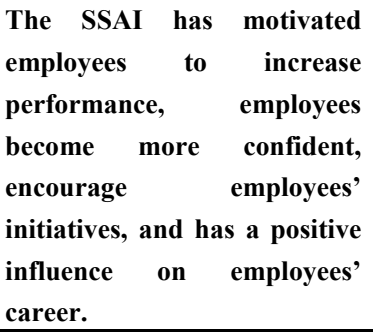 & 3.21 & 3.17 & 3.10 & 3.11 & .947 & 3.20 & 3.24 & 3.10 & 3.15 & .765 \\
\hline
\end{tabular}

Notes. Significant at the $* 0.05$, Five-point Likert scale.

\section{Conclusions}

Given the fact that the SSAI through their performance audit, is expected to exert influence on public organisations for better governance and greater accountability in the management of public funds, It is fair to examine whether these organisations have complied with the influence exerted and change the way they manage public resources accordingly. We do not claim that this research has revealed all knowledge about the impact of the SSAI on public organisations. But it has made a major theoretical and practical contributions to that goal. We agree with Lansdale (2000), and Morin (2014) that it is extremely difficult to precisely measure the impact of performance audit on public organisations. At the same time, we also agree with Raudla et al. (2015) that this measurement is a worthwhile endeavor.

Existing researches often examine the impact of performance audit from the auditors perspective. This is more likely to bias the reality, since auditors are expected to overestimate the usefulness of their work (Morin, 2008). Our study examines the impact of performance audit on Saudi public organisations as perceived by administrators (auditees). This is more likely provide better understanding of the performance of the SSAI. In addition, we examine the impact of administrators' personal factors on the process of performance audits, and whether these factors could improve administrators' understanding of auditors' missions and accordingly facilitate their compliance with auditors' influence.

The broad theme emerges from our study is that the SSAI can claim a remarkable achievements, in terms of 
improving Saudi public affairs. In contrast with Friedberg and Lutrin (2005), this study shows that the cost incurred on performance audit is a worthwhile investments. Administrators, irrespective of their experience and qualifications have shown positive experiences from the process of performance audit and that they are convinced of the usefulness and the quality of the SSAI's reports. This study reveals that the SSAI has contributed towards helping the managements of public organisations to define their priorities and adopt both strategic and operational plans. It has also help them to evaluate their projects and services, identify problems and shortcoming of these projects and services and then provide valuable recommendations to rectify them.

In terms of power, consistent with Alwardat et al. (2015), this study shows that auditors enjoy a statutory or coercive power since they belong to the SSAI which has a strong constitutional support and a mandate for conducting audit in public organisations. They are acting as watchdogs for the Saudi Government and required to hold administrators accountable for the use of public resources. This indicates that they have earn the necessary legitimacy power (Porter et al., 2003) to influence public administrations. The analysis reveals that administrators expect a certain pattern of auditor-exerted influence. This influence appears in administrators' tendency to: comply with the laws and regulations governing their organisations; work hard to set up effective control systems to reduce fraud, dishonesty and waste of public resources; identifying more accurate and reliable performance indicators, and; emphasise on transparency by disclosing more reliable information about their organisations' performance.

This study contributes to the existing literature about the importance of performance audit to improve accountability in public sector organisations. It has enhanced the understanding of the influence of performance audits and the contributions they made in improving public administrations performance. There are also two new angles of our study, First: it examines the impact of the administrators personal factors, which have been mentioned above on the process of performance audits and how these factors could facilitate or otherwise, the undertaking of real changes in the way that public resources are managed by administrators, and Second; it examines the impact of performance audits in one of the developing countries, which has recently started to adopt the components of performance audits as well as financial audit in its public organisations. Bawole and Ibrahim (2016) suggested that what constitutes good public sector performance differs across disciplines, countries and organisations.

In addition, the study shows that reward power (French and Raven, 1959) is obvious in the Saudi public organisations and the SSAI' auditors' relationship. Consistent with Morin (2015) our study shows that administrators enjoy an implicit reward as a result of their cooperations with the SSAI' auditors. Administrators were satisfied with the performance of the SSAI since it has encouraged them to be more efficient and more effective. They also become more confident and forward looking. This has helped them maintain good relationship with their superiors and subordinates and have an opportunity to exchange ideas and communicate personnel information about orientations and missions of their organisations.

Finally, the small number of participants was the main limitation of this study. Although we have made enormous effort to include more participants from different public organisations, but some of the targeted participants were reluctant to take part of the study. The door is wide open for future research in other administrations.

\section{References}

Alwardat, Y., Benamraoui, H., \& Rieple, A. (2015). Value for money and audit practices in the UK public sector. International Journal of Auditing, 19, 206-217. https://doi.org/10.1111/ijau.12037

Arnaboldi, M., \& Lapsley, I. (2008). Making management auditable: the implementation of best value in Local Government. Abacus, 44(1), 22-47. https://doi.org/10.1111/j.1467-6281.2007.00247.x

Bawole, J. N., \& Ibrahim, M. (2016). Contesting Claims on Measuring Performance in the Public Sector Using Performance Audits: Evidence from the Literature. Public Organisation Review, 16(3), 285-299. https://doi.org/10.1007/s11115-015-0312-4

Behn, R. (2001). Rethinking democratic accountability. Washington: Brookings Institution Press.

Bemelmans-Videec, M. L., Lonsdale, J., \& Perrin, B. (2007). Making accountability work. New Brunswick: Transaction Publishers.

Benish, A., \& Levi-Faur, D. (2012). New forms of administrative law in the age of third-party Government. Public inistration, 90(4), 886-900. https://doi.org/10.1111/j.1467-9299.2012.02037.x

Christensen, T., Laegreid, P., \& Roness, P. G. (2002). Increasing parliamentary control of the executive? New 
instruments and emerging effects. The Journal of Legislative Studies, 8(1), 37-62. https://doi.org/10.1080/714003902

Dahl, R. A. (1957). The concept of power. Behavioural Science, 2, 201-215. https://doi.org/10.1002/bs.3830020303

De Lancer Julnes, P. (2006). Performance measurement. Evaluation, 12(2), 219-35. https://doi.org/10.1177/1356389006066973

De Vries, G. J., Van der Meer, F. B., \& Vissers, G. (2000). Evaluation and organizational learning in Government: the impact of institutions. Social Science Electronic Publishing Retrieved from http://papers.ssrn.com/sol3/papers.cfm?abstract_id = 1579592; accessed 13 April 2012

Dunn, J. (1996). Auditing: Theory \& practice. Prentice Hall.

French, J. R., \& Raven, B. H. (1959) 'The bases of social power. In Cartwright, D (Ed.), Studies in social power. University of Michigan Press.

Goldman, A., \& Barlev, B. (1974). The auditor-firm conflict of interests: its implications for independence. The Accounting Review, 707-718.

Gronlund, A., Svardsten, F., \& Ohman, P. (2011). Value for money and the rule of law: The (new) performance audit in Sweden. International Journal of Public Sector Management, 24(2), 107-121. https://doi.org/10.1108/09513551111109026

Hood, C. (1991). A Public management for all seasons? Public Administration, 69(1), 3-19. https://doi.org/10.1111/j.1467-9299.1991.tb00779.x

INTOSAI (International Organisational of Supreme Audit Institutions). (1997). Standards and guidelines for performance auditing based on INTOSAI's audinting standards and practical experience. Retrieved from http://www.intosai.org/uploads/4124efestschrift

INTOSAI (International Organisational of Supreme Audit Institutions). (2004). Standards and guidelines for performance auditing based on INTOSAI's audinting standards and practical experience. ISSAI

Jensen, M. C., \& Meckling, W. H. (1976). Theory of the firm: Managerial behavior, agency cost and ownership structure. Journal of Financial Economics, 3(4), 304-360. https://doi.org/10.1016/0304-405X(76)90026-X

Johnsen, A., Meklin, P., Oulasvirta, L., \& Vakkuri, J. (2001). Performance auditing in local Government: An exploratory study of perceived efficiency of municipal value for money auditing in Finland and Norway. European Accounting Review, 10(3), 583-599. https://doi.org/10.1080/09638180126803

Justesen, L., \& Skaerbaek, P. (2010). Performance auditing and the narrating of a new audit Identity. Financial Accountability \& Management, 26(3), 325-343. https://doi.org/10.1111/j.1468-0408.2010.00504.x

Keen, J. (1999). On the nature of audit judgments: The case of value for money studies. Public Administration, 77(3), 509-625. https://doi.org/10.1111/1467-9299.00165

Kells, S. (2011). The seven deadly sins of performance auditing: implications for monitoring public audit institutions. Australian Accounting, 21(4), 383-396. https://doi.org/10.1111/j.1835-2561.2011.00150.x

Lapsley, I., \& Pong, C. (2000). Modernization versus problematisation: value-for-money audit in public services. European Accounting Review, 9(4), 541-567. https://doi.org/10.1080/713764876

Ling, T. (2007). New Wine in Old Bottles? When audit, accountability and evaluation meet, in M.-L. Belmans-Videc, J. Lonsdale and B. Perrin (Eds.), Making accountability work (pp. 127-141). New Brunswick, NJ: Transaction Publishers.

Lonsdale, J. (1999). Impacts. In Pollitt, C., Xavier, C., Lonsdale, J., Mul, R. and Waerness, M. (Eds.), Performance audit and public management in five countries (pp.171- 193). Oxford: Oxford University Press. https://doi.org/10.1093/acprof:oso/9780198296003.003.0010

Lonsdale, J. (2000). Developments in value-for-money audits: impacts and implications. International review of Administrative Sciences, 66, 73-89. https://doi.org/10.1177/0020852300661007

Morin, D. (2001). Influence of value for money audit on public administrations: looking beyond Appearances. Financial Accountability \& Management in Governments, Public Services and Charities, 17(2), 99-117. https://doi.org/10.1111/1468-0408.00123

Morin, D. (2004). Measuring the impact of value-for-money audits: A model for surveying audited managers. 
Administration publique du Canada/Canadian Public Administration, revue de l'Institut d'administration publique du Canada, 47(2), 141-164. https://doi.org/10.1111/j.1754-7121.2004.tb01181.x

Morin, D. (2008). Auditors general' s universe revisited: an exploratory study of the influence they exert on public administration through their value for money audits. Managerial Auditing Journal, 23(7), 697-720. https://doi.org/10.1108/02686900810890652

Morin, D. (2014). Auditors general's impact on administrations: A pan-Canadian study (2001-2011). Managerial Auditing Journal, 29(5), 395-426. https://doi.org/10.1108/MAJ-10-2013-0948

Morin, D. (2014). Democratic accountability during performance audits under pressure: A recipe for institutional hypocrisy?

Nichols, D. R., \& Price, K. H. (1976). The auditor-firm conflict: an analysis using concepts of exchange theory. The Accounting Review, 51(2), 335-346.

Nutley, S., Levitt, R., Solesbury, W., \& Martin, S. (2012). Scrutinizing performance: How assessors reach judgements about public services. Public Administration, 90(4), 869-885. https://doi.org/10.1111/j.1467-9299.2011.02022.x

Pfeffer, J., \& Salancik, G. R. (1975). Determinants of supervisory behaviour: A role set analysis'. Human Relations, 28(2), 139-154. https://doi.org/10.1177/001872677502800203

Pollitt, C. (2003). Performance audit in western Europe: trends and choices. Critical Perspectives on Accounting, 14, 157-170. https://doi.org/10.1006/cpac.2002.0521

Pollitt, C., \& Bouckaert, G. (2004). Public management reform: A comparative analysis. Oxford: Oxford University Press.

Pollitt, C., \& Summa, H. (1997). Reflexive watchdogs? How supreme audit institutions account for Themselves. Public Administration, 75, 313-336. https://doi.org/10.1111/1467-9299.00063

Pollitt, C., Girre, X., Lonsdale, J., Mul, R., Summa, H., \& Waerness, M. (1999). Performance or compliance? performance audit and public management in five countries. Oxford: Oxford University Press. https://doi.org/10.1093/acprof:oso/9780198296003.001.0001

Power, M. (1994a). Auditing: is there too much of a good thing? Accountancy, 114(1211), 75-75.

Power, M. (1997). The audit society: rituals of verification. Oxford: Oxford University Press.

Power, M. (2003a). Evaluating the audit explosion. Law \& Policy, 25(3), 185-202. https://doi.org/10.1111/j.1467-9930.2003.00147.x

Radula, R., Taro, K., Agu, C., \& Douglas, J.W. (2015). The impact of performance audit on public sector organisations: The case of Estonia. Public Organisation Review, 1-17.

Reichborn-Kjennerud, K. (2013). Political accountability and performance audit: the case of the auditor-general in Norway. Public Administration, 9(3), 680-695. https://doi.org/10.1111/padm.12025

Reichbourn-Kjennerud, K., \& Johnsen, A. (2015). Performance audit and supreme audit institutions' impact on public administration: the case of the office of the auditor general in Norway. Administration \& Society, 1-25. https://doi.org/10.1177/0095399715623315

Talbot, C. (2010). Theories of performance: Organizational and service improvement in the publicdomain. Oxford: Oxford University Press.

Talbot, C., \& Wiggan, J. (2010). The public value of the National Audit Office. International Journal of Public Sector Management, 23(1), 54-70. https://doi.org/10.1108/09513551011012321

Tillema, S., \& Ter Bogt, H. J. (2010). Performance auditing: Improving the quality of political and democratic processes? Critical Perspectives on Accounting, 21(8), 754-769. https://doi.org/10.1016/j.cpa.2010.06.001

Van der Meer, F. B. (1999). Evaluation and the social construction of impacts. Evaluation, 5(4), 387-406. https://doi.org/10.1177/135638999400830048

Van Loocke, E., \& Put, V. (2011). The impact of performance audits: a review of the existing evidence. In Lonsdale, J., Wilkins, P., \& Ling, T. (Eds), Performance auditing - contributing to accountability in democratic government ( Chapter 9, pp.175-208). https://doi.org/10.4337/9780857931801.00016

Waring, C., \& Morgan, S. (2007). Performance accountability and combating corruption (p. 448). Washington: The World Bank. 
Weets, K. (2011). Impact at local government level: A multiple case study. In J. Lonsdale, P. Wilkins, \& T. Ling (Eds.), Performance auditing: Contributing to accountability in democratic government (pp. 48-267). Massachusetts: Edward Edgar Publishing. https://doi.org/10.4337/9780857931801.00019

Wilkins, P., \& Lonsdale, J. (2007). Public sector auditing for accountability: new directions, new tricks? In Wilkins, P. and Lonsdale, J., (Ed.), Making Accountability Work, New Brunswick (U.S.A) and London (U.K.).

\section{Copyrights}

Copyright for this article is retained by the author(s), with first publication rights granted to the journal.

This is an open-access article distributed under the terms and conditions of the Creative Commons Attribution license (http://creativecommons.org/licenses/by/4.0/). 